\title{
Cellular Heterogeneity of Ammonium lon Transport across the Basolateral Membrane of the Hamster Medullary Thick Ascending Limb of Henle's Loop
}

Shuichi Tsuruoka, Masahiro Takeda, Koji Yoshitomi, and Masashi Imai

Department of Pharmacology, Jichi Medical School, Tochigi 329-04, Japan

\begin{abstract}
The epithelia of the medullary thick ascending limb (MAL) consists of two cell types, high (HBC) and low basolateral conductance ( $\mathrm{LBC}$ ) cell, depending on the $\mathrm{K}^{+}$conductance of the basolateral membrane. The $\mathrm{NH}_{4}^{+}$conductance distinct from the $\mathrm{K}^{+}$conductance has been suggested to exist in the proximal tubule, MAL cell, and Xenopus oocyte. The present study was designed to examine whether there is a conductive $\mathrm{NH}_{4}^{+}$transport system distinct from $\mathrm{K}^{+}$conductance in two different cell types of the hamster MAL perfused in vitro. The basolateral membrane voltage ( $V_{B}$ ) was measured by impaling cells with conventional microelectrodes. Addition of $\mathrm{NH}_{4}^{+}$to the bath depolarized $V_{B}$ in a dose-dependent manner in both cell types. The response was maintained in the absence of $\mathrm{HCO}_{3}^{-}$. When the $\mathrm{VB}$ deflection elicited upon $50 \mathrm{mM} \mathrm{KCl}$ or $\mathrm{NH}_{4} \mathrm{Cl}$ in the bath ( $\Delta V_{B_{K^{+}}}$or $\left.\Delta V_{B_{N_{4}}^{+}}\right)$were compared, $\Delta V_{B_{N_{4}^{+}}^{+}}$was almost the same as $\Delta V_{B_{K^{+}}}$in the $H B C$ cell, whereas the former was greater than the latter in the $\mathrm{LBC}$. In the $\mathrm{HBC}$ cell, $10 \mathrm{mM}$ $\mathrm{Ba}^{2+}$ in the bath equally suppressed both $\Delta \mathbf{V B}_{\mathrm{K}}+$ and $\Delta \mathbf{V B}_{\mathrm{NH}_{4}^{+}}$, whereas in the $L B C$ cell it suppressed $\Delta V_{B_{K}+}$ with a small effect on $\Delta \mathrm{VB}_{\mathrm{NH}_{4}^{+}}$, indicating that $\mathrm{NH}_{4}^{+}$is transported via a pathway distinct from $\mathrm{Ba}^{2+}$-sensitive $\mathrm{K}^{+}$conductance. The $\mathrm{VB}_{\mathrm{B}}$ deflection by $\mathrm{NH}_{4}^{+}$was unaffected by addition of $0.1 \mathrm{mM}$ ouabain or $10 \mu \mathrm{M}$ 5-nitro-2-(3-phenylpropylamino)-benzoate (a $\mathrm{Cl}^{-}$channel blocker) to the bath, excluding the contribution of the $\mathrm{Na}^{+}, \mathrm{K}^{+}$pump or $\mathrm{Cl}^{-}$channel. An abrupt reduction of $\mathrm{Na}^{+}$ in the bath from 200 to $20 \mathrm{mM}$ did not cause any changes in $\mathrm{VB}_{B}$, suggesting that a nonselective cation channel may not account for the $\mathrm{NH}_{4}^{+}$transport. Amiloride at $10 \mu \mathrm{M}$ inhibited $\Delta \mathrm{VB}_{\mathrm{NH}_{4}^{+}}$ with a higher efficacy in the $L B C$ cell. We conclude that a rheogenic $\mathrm{NH}_{4}^{+}$transport system independent from the $\mathrm{K}^{+}$conductance exists in the basolateral membrane of the $L B C$ cell of the hamster MAL, and may play some roles in the regulation of $\mathrm{NH}_{4}^{+}$transport. (J. Clin. Invest. 1993. 92:1881-1888.) Key words: ammonium transport $-\mathrm{Ba}^{2+}$-sensitive $\mathrm{K}^{+}$channel $\bullet$ Henle's loop $\bullet \mathrm{K}^{+}$conductance $\bullet \mathrm{NH}_{4}^{+}$conductance
\end{abstract}

\section{Introduction}

Ammonium transport in the kidney plays an important role in urinary acid excretion $(1,2)$. Good et al. (3) demonstrated for the first time that, in the thick ascending limb of Henle's loop,

Address reprint requests to Dr. Masashi Imai, Department of Pharmacology, Jichi Medical School, Minamikawachi, Kawachi, Tochigi 32904, Japan.

Received for publication 24 March 1993 and in revised form 17 May 1993.

\section{J. Clin. Invest.}

(C) The American Society for Clinical Investigation, Inc.

$0021-9738 / 93 / 10 / 1881 / 08 \$ \$ 2.00$

Volume 92, October 1993, 1881-1888 the ammonium ion $\left(\mathrm{NH}_{4}^{+}\right)$is directly transported as opposed to the nonionic diffusion of $\mathrm{NH}_{3}$. Subsequent studies by Garbin et al. (4) and Good (5) suggested that the greatest fraction of $\mathrm{NH}_{4}^{+}$absorbed in this segment is mediated by a secondary active process through a $\mathrm{Na}^{+}-\mathrm{NH}_{4}^{+}-2 \mathrm{Cl}^{-}$cotransport across the apical membrane.

Several lines of evidence supported the view that $\mathrm{NH}_{4}^{+}$substitutes for $\mathrm{K}^{+}$on $\mathrm{Na}^{+}-\mathrm{K}^{+}-2 \mathrm{Cl}^{-}$cotransporter in the apical membrane. First, Kinne et al. (6) demonstrated in apical membrane vesicles from rabbit thick ascending limbs that the $\mathrm{NH}_{4}^{+}$gradient, as well as the $\mathrm{K}^{+}$gradient, can drive bumetanide-sensitive ${ }^{22} \mathrm{Na}$ uptake. Second, Good (5) demonstrated in the rat thick ascending limb that $\mathrm{K}^{+}$in the lumen competitively inhibits $\mathrm{NH}_{4}^{+}$absorption. Third, Garvin et al. (4) reported that furosemide inhibits the active $\mathrm{NH}_{4}^{+}$absorption independent of its effect on the transmural voltage. Fourth, they further showed that the complete replacement of $\mathrm{K}^{+}$by $\mathrm{NH}_{4}^{+}$ maintains the active $\mathrm{Cl}^{-}$transport across the thick ascending limb. Finally, Kikeri et al. (7) demonstrated that, in the mouse thick ascending limb, the luminal addition of $\mathrm{NH}_{4}^{+}$causes a marked decrease in intracellular $\mathrm{pH}$, indicating that $\mathrm{NH}_{4}^{+}$ rather than $\mathrm{NH}_{3}$ preferentially crosses the apical membrane.

The major route for net ammonia absorption across the thick ascending limb thus established is as follows: $\mathrm{NH}_{4}^{+}$enters cell across the apical membrane and dissociates in the cell to proton and $\mathrm{NH}_{3}$, the latter of which exits across the basolateral membrane by simple passive diffusion. In contrast, the possible existence of other routes for $\mathrm{NH}_{4}^{+}$transport across cell membranes of the thick ascending limb is less well known. Although it is possible that $\mathrm{NH}_{4}^{+}$is also transported via $\mathrm{K}^{+}$conductance in the apical membrane, the results reported by several groups of investigators are controversial. Garvin et al. (4) reported that, in rat thick ascending limb, there was net $\mathrm{NH}_{4}^{+}$flux which was not inhibited by furosemide. Kikeri et al. (7) reported that, in mouse thick ascending limb, barium partially blocked the entry of $\mathrm{NH}_{4}^{+}$from the apical membrane. However, Kinne et al. (6) reported that bumetanide-insensitive ${ }^{86} \mathrm{Rb}$ uptake in apical membrane vesicles of the rabbit thick ascending limb was not affected by $\mathrm{NH}_{4}^{+}$. Furthermore, a patch clamp study on the apical membrane of the thick ascending limb showed that the $\mathrm{K}^{+}$channel is less conductive to $\mathrm{NH}_{4}^{+}$and that $\mathrm{NH}_{4}^{+}$ rather inhibits $\mathrm{K}^{+}$current (8).

Yoshitomi et al. (9) reported that, in the hamster medullary thick ascending limb of Henle's loop (MAL), ${ }^{1}$ there are two cell types: one having a high basolateral membrane con-

1. Abbreviations used in this paper: $\mathrm{HBC}$, high basolateral membrane conductance; LBC, low basolateral membrane conductance; MAL, medullary thick ascending limb; NPPB, 5-nitro-2-(3-phenylpropyl-

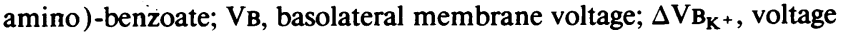
deflection of basolateral membrane induced by $50 \mathrm{~K}^{+}$solution in the bath; $\Delta \mathbf{V}_{\mathrm{NH}_{4}^{+}}$, voltage deflection of basolateral membrane induced by $50 \mathrm{NH}_{4}^{+}$solution in the bath. 
ductance (HBC) and the other having a low basolateral membrane conductance (LBC). They are comparable to those reported for the early distal tubule of the Amphiuma kidney (10). Distinguishing between these cell types is critically dependent on the difference in the magnitude of basolateral membrane $\mathrm{K}^{+}$conductance. Although $\mathrm{NH}_{4}^{+}$is known to share various transport mechanisms with $\mathrm{K}^{+}$as mentioned above, lines of evidence have accumulated in support of the view that there is an $\mathrm{NH}_{4}^{+}$conductance which is distinct from the $\mathrm{K}^{+}$ conductance. Völkl and Lang (11) found that, in the mouse straight proximal tubule, a rheogenic $\mathrm{NH}_{4}^{+}$entry mechanism exists in the basolateral membrane. Bichara et al. (12) made a preliminary report on the existence of $\mathrm{NH}_{4}^{+}$conductance in the rat MAL cell preparation through measuring intracellular $\mathrm{pH}$ and voltage by fluorometry. Burckhardt and Frömter (13) also found $\mathrm{NH}_{4}^{+}$conductance distinct from the $\mathrm{K}^{+}$conductance in Xenopus oocyte. Independent of these studies, we have also noticed while we were studying paracellular conductance of $\mathrm{NH}_{4}^{+}$in the segments of Henle's loop that increases in $\mathrm{NH}_{4}^{+}$ concentration in the bath caused marked depolarization of the basolateral membrane voltage. Therefore, the present study was designed to examine whether there is a conductive $\mathrm{NH}_{4}^{+}$ transport system distinct from the $\mathrm{K}^{+}$conductance in two different cell types of the hamster MAL perfused in vitro. In this study we found that there is remarkable cell heterogeneity with regard to the basolateral membrane $\mathrm{NH}_{4}^{+}$conductance which is distinct from the $\mathrm{K}^{+}$conductance.

\section{Methods}

In vitro microperfusion. Male or female golden hamsters weighing 60 $110 \mathrm{~g}$ were maintained on regular laboratory diet and allowed free access to tap water ad libitum. On the days of experiments, the animals were decapitated with a guillotine. Both kidneys were removed and placed in a dish containing modified Collins solution of the following composition (mM); $14 \mathrm{KH}_{2} \mathrm{PO}_{4}, 44 \mathrm{~K}_{2} \mathrm{HPO}_{4}, 15 \mathrm{KCl}, 9 \mathrm{NaHCO}_{3}$,

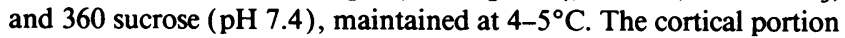
was removed by fine forceps and the remaining block of renal medulla was transferred to another dish, which contained the same solution. Segments of the MAL were isolated with fine forceps under a stereomicroscope. Isolated renal tubules were transferred to a perfusion bath mounted on an inverted microscope (IMT 2-21, Olympus, Tokyo) and perfused in vitro at $37^{\circ} \mathrm{C}$ according to the method of Burg et al. (14), as modified previously (9). A system of a flow-through bath was utilized to permit rapid exchange of the bathing fluid. The bathing fluid was maintained at $37^{\circ} \mathrm{C}$ by supplying through a warm water jacket. The flow rate of the bathing fluid was ranged from 3 to $5 \mathrm{ml} / \mathrm{min}$. The compositions of solutions used in this study are listed in Table I.

Electrophysiological studies. Transmural voltage $\left(\mathrm{V}_{\mathrm{T}}\right)$ was measured by connecting a $1 \mathrm{M} \mathrm{KCl}$ agar bridge to a saturated $\mathrm{KCl}$ reservoir where a calomel half-cell electrode was placed. The electrode was connected to a dual channel electrometer (Duo 773, WP Instruments, New Haven, CT) and recorded on a two-pen recorder (R-301, Rikadenki, Tokyo). The circuit was completed by connecting to another calomel half-cell electrode, which was connected to the bath with a $1 \mathrm{M}$ $\mathrm{KCl}$ agar bridge, serving as a common ground.

Basolateral membrane voltage was measured by intracellular impalement of the epithelia of perfused segment with a conventional microelectrode fabricated by a vertical puller (PE-2, Narishige, Tokyo). Electrodes were filled with $0.5 \mathrm{M} \mathrm{KCl}$ and connected to another channel of the electrometer via a holder which contains $\mathrm{Ag}-\mathrm{AgCl}$ pellet. The position of electrodes was controlled with manipulators (MO-102M, Narishige) fixed on the stage of the inverted microscope. Impalement of an electrode was conducted by table tapping or current oscillation.

Solutions and chemicals. The composition of the solutions used in this study is listed in Table I. Solutions containing $\mathrm{HCO}_{3}^{-}$were bubbled with $95 \% \mathrm{O}_{2}$ and $5 \% \mathrm{CO}_{2}$ to adjust $\mathrm{pH}$ at 7.4. $\mathrm{HCO}_{3}^{-}$-free solutions were bubbled with $100 \% \mathrm{O}_{2}$. The $\mathrm{pH}$ of those solutions was adjusted to 7.4 by Hepes and Tris. 5-nitro-2-(3-phenylpropylamino)-benzoate (NPPB) was kindly supplied by Hoechst (Frankfurt, FRG). Ouabain and amiloride were purchased from Sigma Chemical Co. (St. Louis, MO).

Data analysis. The initial peak of the change in the basolateral membrane $\left(\Delta V_{B}\right)$ after rapid exchange of the bathing fluid was taken as a value reflecting an apparent conductance of the ion in question. When $\triangle \mathrm{VB}$ induced by adding $50 \mathrm{mM} \mathrm{KCl}$ to the bath was more than $20 \mathrm{mV}$, the cell was regarded to be $\mathrm{HBC}$ cell and others were regarded to be $\mathrm{LBC}$ cell.

All data are expressed as means \pm SE. Statistical analysis was performed by using the Student's $t$ test for paired or unpaired samples when appropriate. $P$ values $<0.05$ were considered as significant.

\section{Results}

$V_{B}$ deflection upon abrupt changes in $\mathrm{K}^{+}$or $\mathrm{NH}_{4}^{+}$concentration in the bath. Impalement of MAL cells with an conventional microelectrode revealed negative basolateral membrane voltage of $\sim 70-80 \mathrm{mV}$, which was stabilized within a few minutes. Initially, we examined effects of abrupt change in $\mathrm{NH}_{4}^{+}$ concentration in the bathing fluid on $\mathrm{VB}_{\mathbf{B}}$ in the solutions containing $25 \mathrm{mM} \mathrm{HCO}_{3}^{-}$bubbled with $95 \% \mathrm{O}_{2} / 5 \% \mathrm{CO}_{2}$. To discriminate between two types of cell, $\mathrm{HBC}$ and $\mathrm{LBC}$ cells, $\mathrm{K}^{+}$ concentration in the bath was increased from 5 to $50 \mathrm{mM}$. In

Table I. Composition of Solutions Used in This Study

\begin{tabular}{|c|c|c|c|c|c|c|c|c|c|}
\hline & $\begin{array}{l}\text { Control } \\
\text { (A) }\end{array}$ & $\begin{array}{l}50 \mathrm{~K}^{+} \\
\text {(A) }\end{array}$ & $\begin{array}{c}50 \mathrm{NH}_{4}^{+} \\
\text {(A) }\end{array}$ & $\begin{array}{c}\mathrm{OHCO}_{3}^{-} \\
\text {(B) }\end{array}$ & $\begin{array}{c}50 \mathrm{~K}^{+} \\
\text {(B) }\end{array}$ & $\begin{array}{c}50 \mathrm{NH}_{4}^{+} \\
\text {(B) }\end{array}$ & $0 \mathrm{Na}^{+}$ & $0 \mathrm{Na}^{+}-50 \mathrm{~K}^{+}$ & $0 \mathrm{Na}^{+}-50 \mathrm{NH}_{4}^{+}$ \\
\hline & \multicolumn{9}{|c|}{$m M$} \\
\hline $\mathrm{NaCl}$ & 200 & 155 & 150 & 215 & 170 & 165 & 0 & 0 & 0 \\
\hline Choline $\mathrm{Cl}$ & 0 & 0 & 0 & 0 & 0 & 0 & 210 & 164 & 160 \\
\hline $\mathrm{NaHCO}_{3}$ & 25 & 25 & 25 & 0 & 0 & 0 & 0 & 0 & 0 \\
\hline $\mathrm{KCl}$ & 5 & 50 & 5 & 5 & 50 & 5 & 5 & 50 & 5 \\
\hline $\mathrm{NH}_{4} \mathrm{Cl}$ & 0 & 0 & 50 & 0 & 0 & 50 & 0 & 0 & 50 \\
\hline Others & $*$ & $*$ & $\ddagger$ & $* \neq$ & $* \neq$ & $* \pm$ & $\$ \$$ & $\neq \S$ & $\$ \S$ \\
\hline
\end{tabular}

All solutions contained 8.3 D-glucose, $5 \mathrm{~L}$-alanine, and 100 urea. When $\mathrm{NH}_{4}^{+}$concentration was varied, $\mathrm{NaCl}$ was replaced by $\mathrm{NH}_{4} \mathrm{Cl}$. $*(\mathrm{mM})$ $=1 \mathrm{MgCl}_{2}+1.8 \mathrm{CaCl}_{2}+0.8 \mathrm{Na}_{2} \mathrm{HPO}_{4}+0.2 \mathrm{NaH}_{2} \mathrm{PO}_{4}+10 \mathrm{Na}$ acetate. ${ }^{\ddagger}(\mathrm{mM})=10$ Hepes $+5 \mathrm{Tris}$. ${ }^{\S}(\mathrm{mM})=1 \mathrm{Mg}$ acetate $+1.8 \mathrm{Ca}$ acetate $+1 \mathrm{KH}_{2} \mathrm{PO}_{4}$. 
support of the observation of Yoshitomi et al. (9), we confirmed that there are two types of cell depending on the magnitude of the voltage deflection of the basolateral membrane in response to $\mathrm{K}^{+}$concentration challenge. After discriminating two cell types, the bathing fluid was changed to solutions of which $\mathrm{NaCl}$ was replaced with various concentrations of $\mathrm{NH}_{4} \mathrm{Cl}$. Representative tracings are shown in Fig. 1. Fig. $1 a$ represents a tracing of a $\mathrm{HBC}$ cell; Fig. $1 b$ shows a LBC cell. In both cells, replacement of $\mathrm{Na}^{+}$with $\mathrm{NH}_{4}^{+}$caused a sharp positive deflection of $V_{B}\left(\Delta V_{B}\right)$ in a dose-dependent manner. The results of 14 experiments are summarized in Fig. $1 \mathrm{c}$. It is noteworthy that the dose-response curve in LBC cell is almost identical to that in HBC cell in spite of the marked difference in

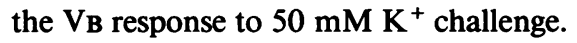

Effect of $\mathrm{HCO}_{3}^{-}$on $\mathrm{VB}$ response to $\mathrm{K}^{+}$and $\mathrm{NH}_{4}^{+}$. Although the $\mathrm{HCO}_{3}^{-}$-containing ambient solutions are physiological, the interpretation on the effect of $\mathrm{NH}_{4}^{+}$may be complicated under such conditions. It is possible that the alkalinization of the cell by diffusion of $\mathrm{NH}_{3}$ may accelerate the extrusion of $\mathrm{HCO}_{3}^{-}$via a rheogenic $\mathrm{Na}^{+}-3 \mathrm{HCO}_{3}^{-}$cotransport which is supposed to exist in the basolateral membrane of the thick ascending limb $(15,16)$, leading to depolarization of the basolateral mem-
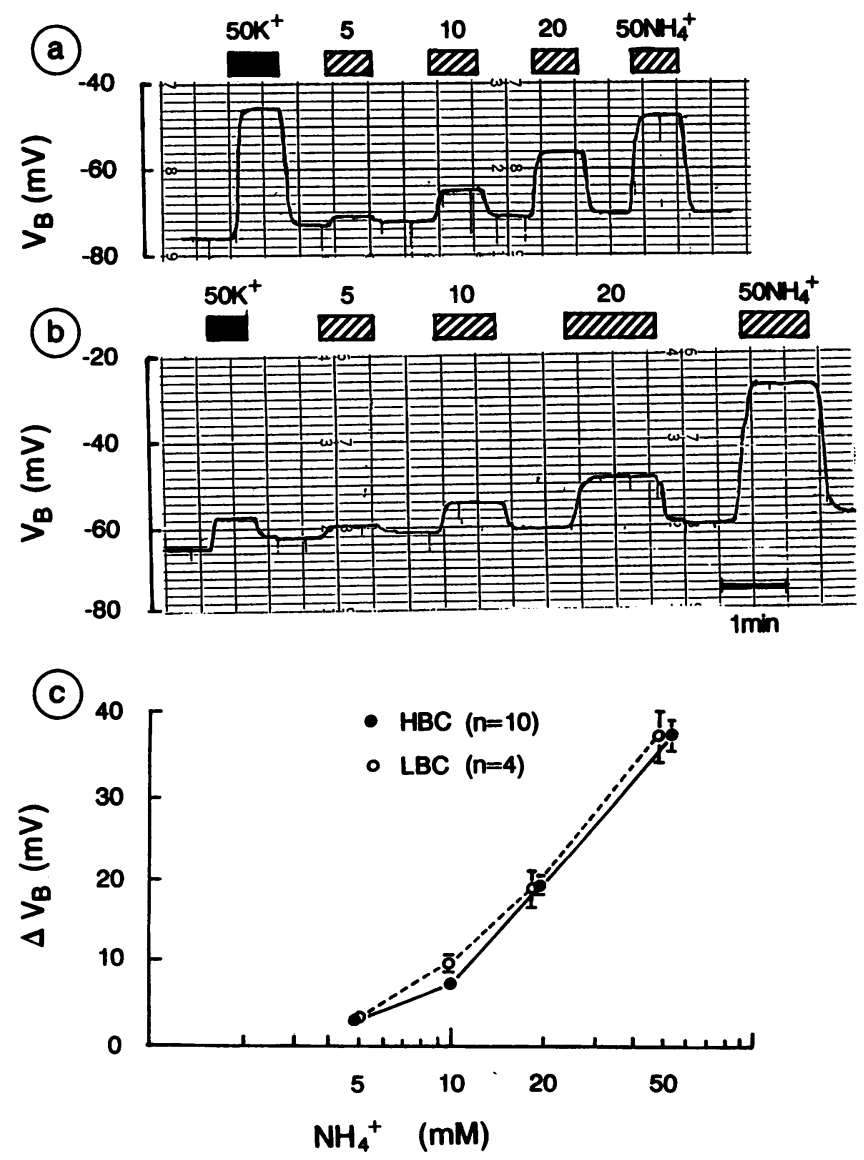

Figure 1. Deflection of basolateral membrane voltage ( $\mathrm{VB}_{B}$ ) upon abrupt changes in concentration of $\mathrm{K}^{+}$or $\mathrm{NH}_{4}^{+}$in the bath. ( $a$ and $b$ ) Representative tracings of $\mathrm{VB}_{B}$ of $\mathrm{HBC}$ cell and $\mathrm{LBC}$ cell, respectively. Note that in spite of big difference of $\mathrm{VB}_{\mathrm{B}}$ response to $50 \mathrm{~K}^{+}$between two cells, the magnitude of the response to $\mathrm{NH}_{4}^{+}$are very similar. (c) Summaries of concentration-dependent $\mathrm{VB}$ responses to $\mathrm{NH}_{4}^{+}$ are shown.

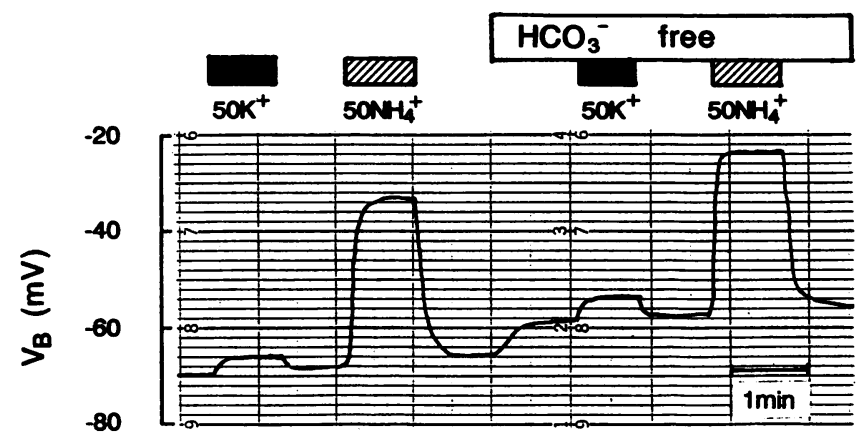

Figure 2. A representative tracing of $\mathrm{VB}$ responses to $50 \mathrm{~K}^{+}$or $50 \mathrm{NH}_{4}^{+}$ in the bath in the presence or absence of $\mathrm{HCO}_{3}^{-}$. The cell is identified as $\mathrm{LBC}$ cell based on the small response to $50 \mathrm{~K}^{+}$.

brane. To estimate the contribution of this component, we examined the effect of $\mathrm{NH}_{4}^{+}$or $\mathrm{K}^{+}$in the bath in the presence or absence of $\mathrm{HCO}_{3}^{-}$in ambient solutions. A representative tracing of the VB of a LBC cell under this protocol is shown in Fig. 2. While the tubule was perfused with A solution, abrupt changes in $\mathrm{K}^{+}$or $\mathrm{NH}_{4}^{+}$in the bathing fluid were conducted to observe changes in $\mathrm{VB}_{\mathrm{B}}$ of the cell with impalement of an electrode. From the responses to $50 \mathrm{~K}^{+}$and $50 \mathrm{NH}_{4}^{+}$, the cell was identified as a $\mathrm{LBC}$ cell. When the bathing fluid was changed to bicarbonate free $B$ solution, the VB depolarized by $9 \mathrm{mV}$. Under this condition, the $\mathrm{VB}$ responses to $50 \mathrm{~K}^{+}$and $50 \mathrm{NH}_{4}^{+}$ were unchanged. The results of this protocol are summarized in Table II. In both HBC and LBC cells, elimination of bicarbonate from the ambient fluid caused significant depolarization of the basolateral membrane. However, the VB responses to $50 \mathrm{~K}^{+}$and to $50 \mathrm{NH}_{4}^{+}$were unchanged in the absence of bicarbonate. The following studies were conducted in the absence of bicarbonate in ambient solutions.

Dissociation of $V_{B}$ responses to $50 \mathrm{~K}^{+}$and $50 \mathrm{NH}_{4}^{+}$challenge. The $\mathrm{VB}_{\mathrm{B}}$ response to a rapid change in ion concentration in the bath is a measure of apparent ion conductance of the basolateral membrane. By random impalement of perfused

Table II. Effect of Elimination of $\mathrm{HCO}_{3}^{-}$on Voltage Responses of the Basolateral Membrane to $50 \mathrm{~K}^{+}$or $50 \mathrm{NH}_{4}^{+}$Challenge in the Bath in the Hamster MAL

\begin{tabular}{lccc}
\hline & $\mathrm{HCO}_{3}^{-}$ & HBC cell & LBC cell \\
\hline & $m M$ & & \\
$n$ & & 4 & 4 \\
$\mathrm{VB}$ & $\mathrm{C} 25$ & $-80.6 \pm 2.8$ & $-65.0 \pm 1.3$ \\
& $\mathrm{E} 0$ & $-68.4 \pm 6.3$ & $-56.5 \pm 2.4$ \\
& $\mathrm{E}-\mathrm{C}$ & $12.2 \pm 3.1^{*}$ & $8.5 \pm 1.8^{\ddagger}$ \\
$\Delta \mathrm{VB}\left(50 \mathrm{~K}^{+}\right)$ & $\mathrm{C} 25$ & $47.0 \pm 1.7$ & $-5.8 \pm 1.2$ \\
& $\mathrm{E} 0$ & $46.0 \pm 1.2$ & $-7.3 \pm 1.0$ \\
$\Delta \mathrm{VB}\left(50 \mathrm{NH}_{4}\right)$ & $\mathrm{E}-\mathrm{C}$ & $-1.0 \pm 0.6$ & $-1.5 \pm 0.5$ \\
& $\mathrm{C} 25$ & $48.5 \pm 2.3$ & $42.8 \pm 3.3$ \\
& E 0 & $45.3 \pm 2.4$ & $40.8 \pm 2.4$ \\
& E-C & $-3.3 \pm 3.7$ & $-2.0 \pm 1.3$
\end{tabular}

Abbreviations: $\mathrm{VB}$, basolateral membrane voltage; $\Delta \mathrm{VB}\left(50 \mathrm{~K}^{+}\right)$, voltage deflection caused by $50 \mathrm{~K}^{+}$solution in the bath; $\Delta \mathrm{VB}\left(50 \mathrm{NH}_{4}^{+}\right)$, voltage deflection caused by $50 \mathrm{NH}_{4}^{+}$solution in the bath; $\mathrm{C}$, control period; E, experimental period. ${ }^{*} P<0.05,{ }^{\ddagger} P<0.01$ as compared to zero. 
MAL with a microelectrode, we compared the magnitude of the voltage deflection caused by $50 \mathrm{~K}^{+}$or $50 \mathrm{NH}_{4}^{+}$solution in the bath. We obtained the data of 101 cells from $66 \mathrm{MAL}$ tubules. The mean $V_{B}$ in the control solution was $-72.6 \mathrm{mV}$. The distribution of $\Delta V_{B}$ by abrupt exposure to $50 \mathrm{~K}^{+}$bath solution $\left(\Delta \mathbf{V B}_{\mathbf{K}^{+}}\right)$clearly show that there are two cell populations with respect to the response to the $\mathrm{K}^{+}$challenge (Fig. 3 ). The $\Delta \mathrm{VB}_{\mathrm{K}}+$ was $40.4 \pm 0.8 \mathrm{mV}$ in $\mathrm{HBC}$ cells and 7.4 $\pm 0.7 \mathrm{mV}$ in $\mathrm{LBC}$ cells. These two cell types were sometimes observed in the same tubules. The basal levels of $V_{B}$ were not different between two groups; $-73.2 \pm 1.0 \mathrm{mV}$ in the $\mathrm{HBC}$ group $(n=63)$ and $-71.6 \pm 1.1 \mathrm{mV}$ in the LBC group $(n=38)$. In spite of clear distinction of $\Delta \mathrm{VB}_{\mathrm{K}^{+}}$, the $\Delta \mathrm{VB}_{\mathrm{B}}$ upon $50 \mathrm{mM} \mathrm{NH}_{4}^{+}$in the bath $\left(\Delta \mathrm{VB}_{\mathrm{NH}_{4}^{+}}\right.$) was not different between two groups; $37.0 \pm 0.9 \mathrm{mV}$ in the HBC cell and $35.3 \pm 0.9 \mathrm{mV}$ in the $\mathrm{LBC}$ cell. In the $\mathrm{HBC}$ cell, $\Delta \mathrm{VB}_{\mathbf{K}^{+}}$was slightly but significantly higher than $\Delta \mathbf{V B}_{\mathbf{N H}_{4}^{+}}$ ( $40.4 \pm 0.8$ vs. $37.0 \pm 0.9 \mathrm{mV}, P<0.01$ ).

Since the thick ascending limb is a leaky segment $(9,17)$, it is possible that the observed $\Delta \mathbf{V}_{\mathrm{K}^{+}}$or $\Delta \mathbf{V B}_{\mathrm{NH}_{4}^{+}}$may be underestimated by the circular current through the paracellular shunt pathway. To exclude this component, we observed $\Delta \mathrm{VB}_{\mathrm{K}^{+}}$or $\Delta \mathrm{VB}_{\mathrm{NH}_{4}^{+}}$in nonperfused renal tubules. The data are summarized in Fig. 4, comparing with the data obtained from perfused renal tubules. In both $\mathrm{HBC}$ and $\mathrm{LBC}$ cells, the $\mathrm{V}_{B}$ responses to $50 \mathrm{~K}^{+}$and to $50 \mathrm{NH}_{4}^{+}$were not different between the perfused and nonperfused tubules. Although the $\mathrm{VB}_{\mathbf{B}}$ response to $\mathrm{NH}_{4}^{+}$was tended to be higher in the nonperfused tubules, the value was not significantly different from that in perfused tubules.

Effect of barium. To examine whether $\Delta \mathbf{V B}_{\mathrm{NH}_{4}^{+}}$represents $\mathrm{NH}_{4}^{+}$transport through a $\mathrm{K}^{+}$conductance, we observed effects of $10 \mathrm{mM} \mathrm{BaCl}$ in the bath on $\Delta \mathrm{VB}_{\mathrm{K}^{+}}$and $\Delta \mathrm{VB}_{\mathrm{NH}_{4}^{+}}$. Representative tracings for each cell type are shown in Fig. 5. In the HBC cell shown in the upper panel, an addition of $10 \mathrm{mM} \mathrm{Ba}^{2+}$ in the bath markedly depolarized the basolateral membrane. In the presence of $\mathrm{Ba}^{2+}$, an abrupt increase in the bath $\mathrm{K}^{+}$concentration to $50 \mathrm{mM}$ further depolarized the basolateral membrane, although the magnitude of the deflection was markedly reduced. This suggests that there are $\mathrm{Ba}^{2+}$ insensitive components for $\mathrm{K}^{+}$conductance. Under the same condition, the challenge with $50 \mathrm{NH}_{4}^{+}$also depolarized the basolateral membrane.

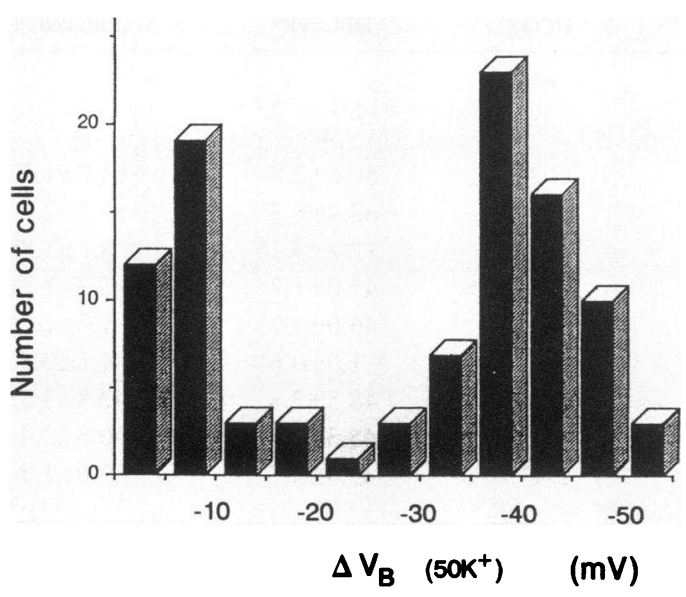

Figure 3. Distribution of $\mathrm{VB}$ response to $50 \mathrm{~K}^{+}$in the bath in randomly punctured hamster MAL cells. It is evident that there are two cell populations.

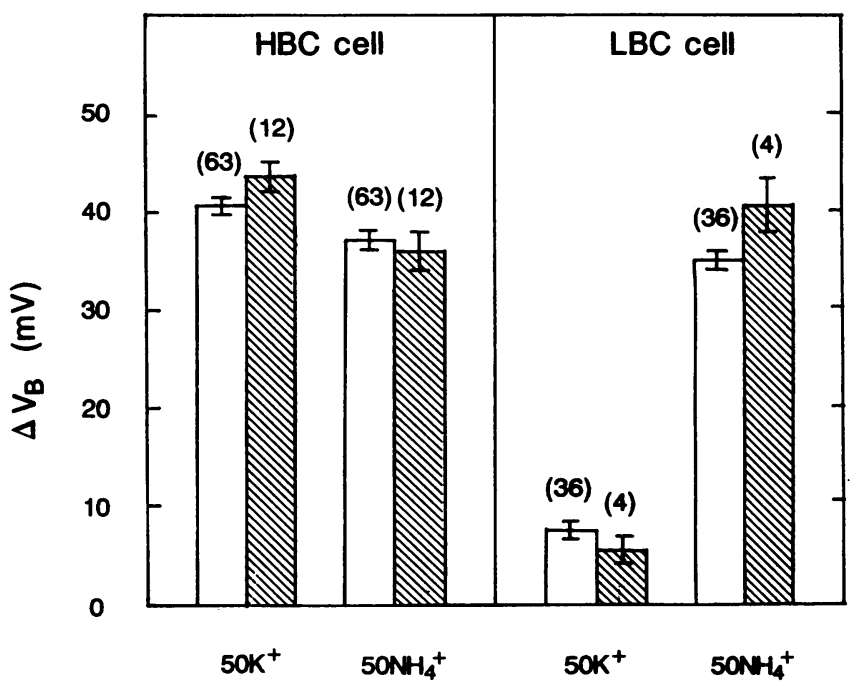

Figure 4. Comparison of $\mathrm{VB}$ responses to $50 \mathrm{~K}^{+}$or $50 \mathrm{NH}_{4}^{+}$between HBC cell and LBC cell. Open columns represent the data obtained from perfused tubules, whereas hatched columns the data from nonperfused tubules. Numbers in parentheses indicate number of cells.

In the LBC cell shown in the lower panel, VB was slightly depolarized by $10 \mathrm{mM} \mathrm{Ba}^{2+}$ in the bath. The $\mathrm{VB}_{\mathrm{B}}$ response to $50 \mathrm{~K}^{+}$ was almost abolished while the $\mathrm{VB}_{\mathrm{B}}$ response to $50 \mathrm{mM} \mathrm{NH}+$ was retained. The results of this series of experiments are summarized in Fig. 6. $\Delta \mathbf{V}_{\mathbf{B}_{K^{+}}}$was inhibited to almost the same degree in both cells $(68.9 \pm 2.4 \%$ in HBC cells $[n=11]$ vs. $73.5 \pm 6.6 \%$ in $\mathrm{LBC}$ cells $[n=7])$. Although in $\mathrm{HBC}$ cells $\Delta \mathrm{VB}_{\mathrm{NH}_{4}^{+}}$was inhibited by $51.2 \pm 3.0 \%$, the inhibition of $\Delta \mathbf{V B}_{\mathbf{N H}_{4}^{+}}$ in $\mathrm{LBC}$ cells was much smaller $(22.9 \pm 1.8 \%)$.

Effect of amiloride. Because Bichara et al. (12) reported that amiloride at a dose that does not affect $\mathrm{Na}^{+} / \mathrm{H}^{+}$antiporter ( $1 \mu \mathrm{M}$ ) inhibited $\mathrm{NH}_{4}^{+}$conductance as assessed by $\mathrm{pH}$ changes in the suspension of rat medullary thick ascending tubules, we examined effects of amiloride on $\Delta \mathrm{VB}_{\mathrm{NH}_{4}^{+}}$. As shown in representative tracings in Fig. 7 , the $\mathrm{VB}$ deflection to $50 \mathrm{~K}^{+}$was slightly decreased in both cells and the $\mathrm{VB}$ deflection to $50 \mathrm{NH}_{4}^{+}$ was markedly reduced in the LBC cell, but slightly reduced in the $\mathrm{HBC}$ cell. In both cells, small but significant depolarizations of the $\mathrm{VB}$ were noted ( $\mathrm{HBC}, \Delta \mathrm{VB}=1.4 \pm 0.3 \mathrm{mV}, n=11$, $P<0.01 ; \mathrm{LBC}, \Delta \mathrm{VB}=0.8 \pm 0.2 \mathrm{mV}, n=6, P<0.01)$ when 10 $\mu \mathrm{M}$ amiloride was added to the bath. These changes, however, are too small to be physiologically significant. In addition, the orientation of the voltage deflection was opposite to that expected from an inhibition of amiloride-sensitive $\mathrm{Na}^{+}$channel. As summarized in Fig. 8, in the presence of $10 \mu \mathrm{M}$ amiloride in the bath, $\Delta \mathrm{VB}_{\mathrm{K}_{\mathrm{K}}}+$ was slightly inhibited by $10.9 \%$ in $\mathrm{HBC}$ cells and by $3.2 \%$ in LBC cells. These inhibition rates were not significantly different. The response of $\Delta \mathrm{VB}_{\mathrm{NH}_{4}^{+}}$was somewhat different. In HBC cells an addition of amiloride inhibited $\Delta \mathbf{V B}_{\mathbf{N H}_{4}^{+}}$ by $22.5 \pm 3.1 \%$, whereas in LBC cells by $50.5 \pm 6.6 \%$. The inhibition was more prominent in LBC cells $(P<0.01)$. These results suggest that there is an amiloride sensitive $\mathrm{NH}_{4}^{+}$conductance predominantly in the LBC cell.

Effect of NPPB. To exclude the possibility that $\mathrm{NH}_{4}^{+}$loading increases $\mathrm{Cl}^{-}$conductance of the basolateral membrane due to changes in intracellular $\mathrm{pH}$, we examined $\Delta \mathrm{V}_{\mathrm{B}^{+}}$or $\Delta \mathrm{VB}_{\mathrm{NH}_{4}^{+}}$in the presence of $10 \mu \mathrm{M}$ 5-nitro-2-(3-phenylpropylamino)-benzoate (NPPB), a $\mathrm{Cl}^{-}$channel blocker (18). When 


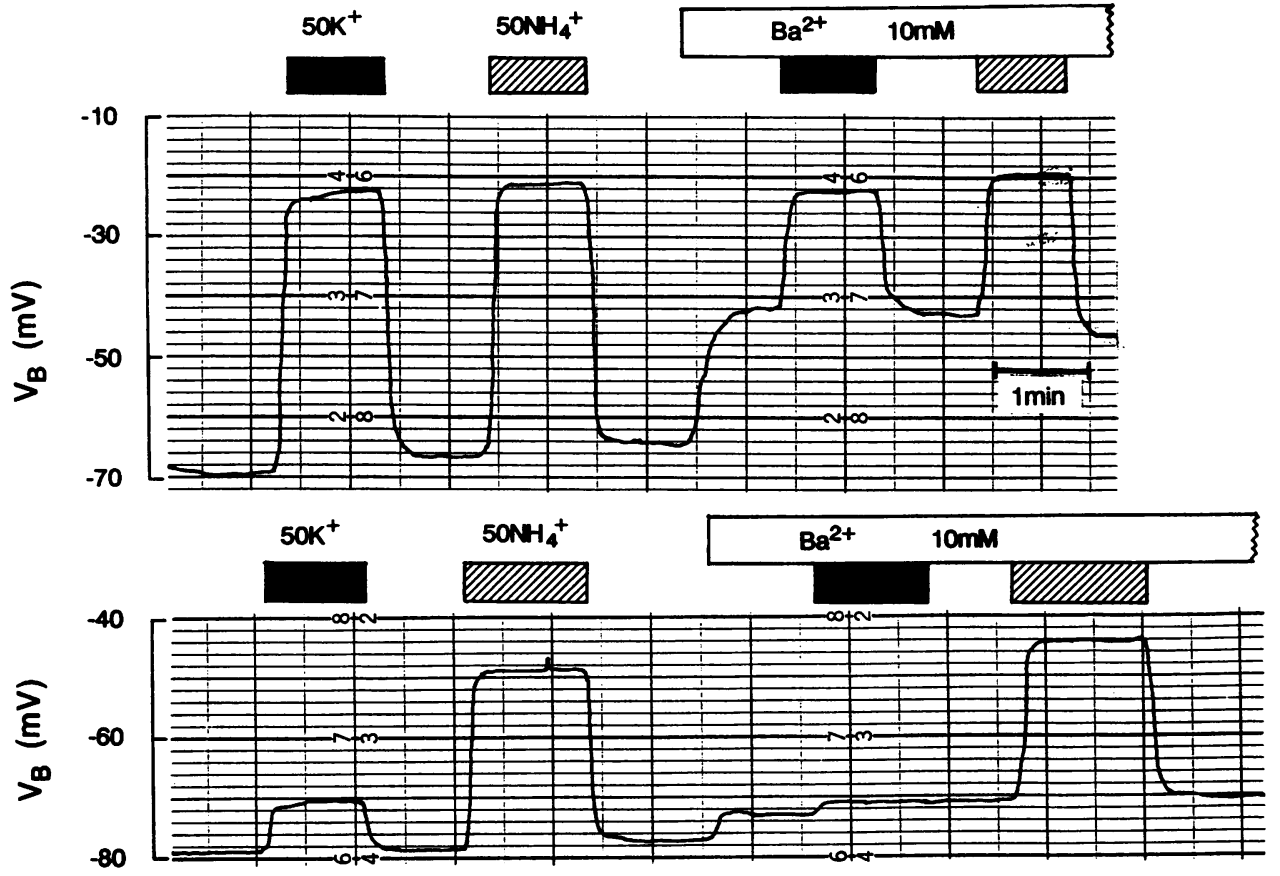

Figure 5. Representative tracings showing $\mathrm{VB}_{\mathrm{B}}$ responses to $50 \mathrm{~K}^{+}$or $50 \mathrm{NH}_{4}^{+}$in the presence or absence of $\mathrm{Ba}^{2+}$ in the bath. The upper pane represents the $\mathrm{HBC}$ cell, and the lower panel represents the LBC cell.

$10 \mu \mathrm{M}$ NPPB was added to the bath the VB of both HBC and LBC cells tended to hyperpolarize from $-75.1 \pm 4.8$ to $-81.7 \pm 4.7 \mathrm{mV}(n=10, P<0.01)$ and from $-68.5 \pm 3.3$ to $-77.7 \pm 2.5 \mathrm{mV}(n=6, P<0.05)$, respectively. As summarized in Table III, the responses of $\Delta \mathbf{V B}_{\mathrm{K}^{+}}$and $\Delta \mathrm{VB}_{\mathrm{NH}_{4}^{+}}$were not different in the presence or absence of NPPB in both cell types.

Effect of elimination of $\mathrm{Na}^{+}$. Because Burckhardt and Frömter (13) suggested that in Xenopus oocyte a nonselective cation channel might be responsible for $\mathrm{NH}_{4}^{+}$conductance, we tested whether $\mathrm{Na}^{+}$conductance is detectable in the basolateral membrane of the hamster MAL. When $\mathrm{Na}^{+}$concentration of the bathing fluid was abruptly reduced from 211.6 to $20 \mathrm{mM}$, VB did not change significantly in both cell types (Table IV).

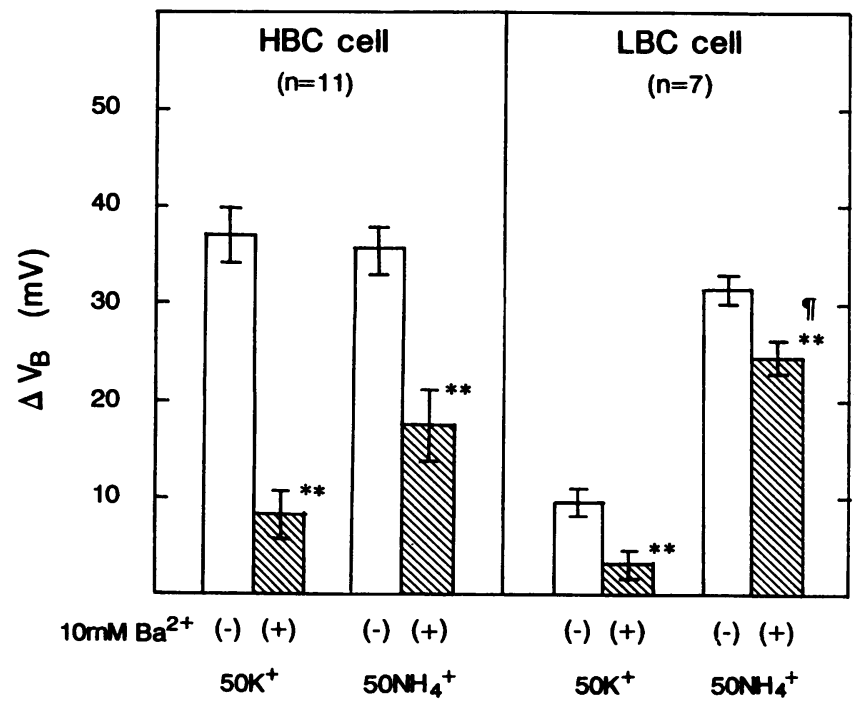

Figure 6. Summary of the data of experiments in which effects of $\mathrm{Ba}^{2+}$ on $\mathrm{VB}$ responses to $50 \mathrm{~K}^{+}$or $50 \mathrm{NH}_{4}^{+}$were observed. ${ }^{* *} P<0.01$ compared to the values without $\mathrm{Ba}^{2+}$. $\llbracket P<0.01$ compared to percent decrease in $\triangle \mathrm{VB}_{\mathrm{NH}}$ in $\mathrm{HBC}$ cell.
Even when $\mathrm{Na}^{+}$was completely eliminated, $\mathrm{VB}$ did not change significantly (Table IV). The responses of $\Delta \mathbf{V}_{\mathbf{K}^{+}}$and $\Delta \mathbf{V B}_{\mathbf{N H}_{4}^{+}}$ were also unchanged under reduced $\mathrm{Na}^{+}$concentration (data not shown).

Effect of ouabain. To assess whether the active $\mathrm{Na}^{+}$transport is required for the response, we examined $\Delta \mathbf{V}_{\mathbf{B}}+$ or $\Delta \mathrm{VB}_{\mathrm{NH}_{4}^{+}}$in the presence of ouabain. The results are summarized in Table V. In seven HBC cells, $10 \mu \mathrm{M}$ ouabain decreased VB from -73.0 to $-48.2 \mathrm{mV}(P<0.001)$. The responses of $\Delta \mathrm{VB}_{\mathrm{K}^{+}}$in the control and ouabain period were 40.2 and 36.0 $\mathrm{mV}$, respectively $(P>0.05)$. The responses of $\Delta \mathrm{VB}_{\mathrm{NH}_{4}^{+}}$in comparable periods were 40.2 and $38.0 \mathrm{mV}$, respectively $(P$ $>0.05$ ). In four LBC cells, $10 \mu \mathrm{M}$ ouabain decreased the $\mathrm{VB}_{\mathrm{B}}$ from -75.5 to $-49.5 \mathrm{mV}(P<0.01)$. The responses of $\Delta \mathrm{V}_{\mathrm{B}_{\mathrm{K}^{+}}}$ in the control and ouabain period were 7.3 and $7.8 \mathrm{mV}$, respectively $(P>0.05)$. The responses of $\Delta \mathrm{VB}_{\mathrm{NH}_{4}^{+}}$in comparable
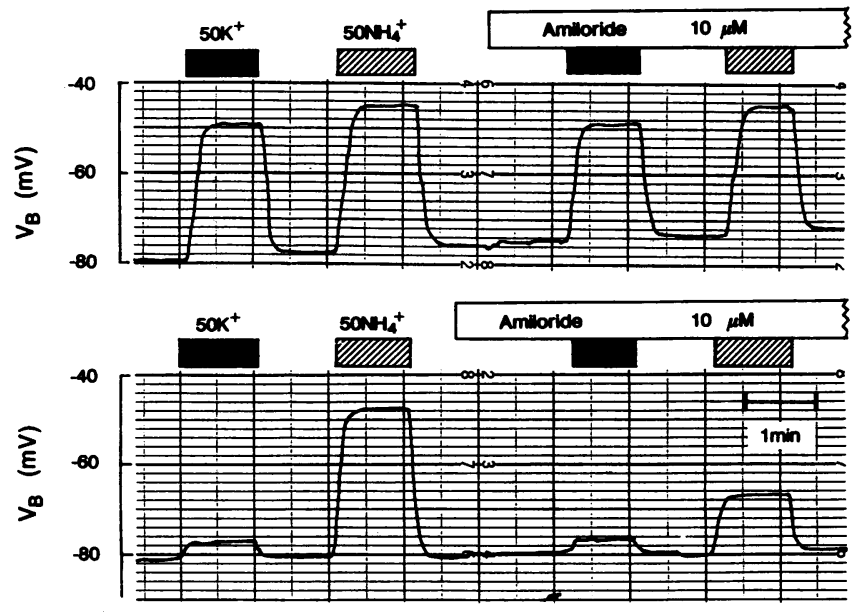

Figure 7. Representative tracings showing $\mathrm{VB}_{\mathrm{B}}$ responses to $50 \mathrm{~K}^{+}$or $50 \mathrm{NH}_{4}^{+}$in the presence or absence of amiloride in the bath. The upper panel represents the HBC cell, and the lower the LBC cell. 


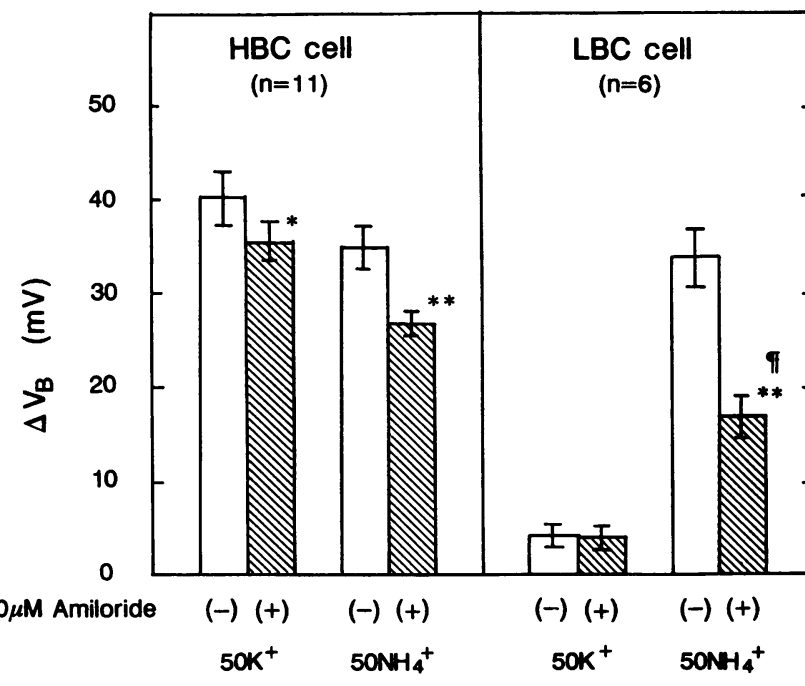

Figure 8. Summary of the data of experiments in which effects of amiloride on $\mathrm{VB}$ responses to $50 \mathrm{~K}^{+}$or $50 \mathrm{NH}_{4}^{+}$were observed. ${ }^{* *} P$ $<0.05, P<0.01$ compared to the values without amiloride. $\| P<$ 0.01 compared to percent decrease in $\Delta \mathrm{VB}_{\mathrm{NH} \downarrow}$ in $\mathrm{HBC}$ cell.

periods were 41.8 and $40.3 \mathrm{mV}$, respectively $(P>0.05)$. These observations indicate that both $\Delta \mathbf{V B}_{\mathrm{K}^{+}}$and $\Delta \mathbf{V}_{\mathbf{N H}_{4}^{+}}$were unaffected by ouabain in both cell types.

\section{Discussion}

Ion transport mechanisms across the membranes of the thick ascending limb of Henle's loop have been well defined by extensive studies of Greger and his associates (17). According to the proposed model, the apical membrane is characterized by the existence of $\mathrm{Na}^{+}-\mathrm{K}^{+}-2 \mathrm{Cl}^{-}$cotransporter and $\mathrm{K}^{+}$conductance, while the basolateral membrane is characterized by $\mathrm{Na}^{+}, \mathrm{K}^{+}$-pump, $\mathrm{K}^{+}$conductance, $\mathrm{Cl}^{-}$conductance, and $\mathrm{K}^{+}$$\mathrm{Cl}^{-}$cotransport. Yoshitomi et al. (9) reported that in the hamster MAL there are two cell types: one having a high basolateral membrane conductance ( $\mathrm{HBC}$ cell) and the other having a low basolateral membrane conductance ( $\mathrm{LBC}$ cell). These two cell types can be identified by the magnitude of the depolarization of the basolateral membrane upon abrupt increase in $\mathrm{K}^{+}$concentration in the bath. In other word, the HBC cell has a high

Table III. Effect of NPPB on Voltage Responses of the Basolateral Membrane to $50 \mathrm{~K}^{+}$or $50 \mathrm{NH}_{4}^{+}$Challenge in the Bath in the Hamster $M A L$

\begin{tabular}{llcc}
\hline & NPPB & HBC cell & LBC cell \\
\hline$n$ & & 10 & 6 \\
$\mathrm{VB}$ & C 0 & $-75.1 \pm 4.8$ & $-68.5 \pm 3.3$ \\
& E $10 \mu \mathrm{M}$ & $-81.7 \pm 4.7$ & $-77.7 \pm 2.5$ \\
& E-C & $-6.6 \pm 1.2 \ddagger$ & $-9.2 \pm 3.2 *$ \\
$\Delta \mathrm{VB}^{*}\left(50 \mathrm{~K}^{+}\right)$ & C 0 & $46.4 \pm 1.6$ & $11.0 \pm 2.7$ \\
& E $10 \mu \mathrm{M}$ & $44.1 \pm 2.5$ & $11.5 \pm 3.3$ \\
& E-C & $-2.3 \pm 2.1$ & $0.5 \pm 2.3$ \\
$\Delta \mathrm{VB}\left(50 \mathrm{NH}_{4}^{+}\right)$ & C 0 & $41.8 \pm 2.3$ & $34.0 \pm 2.4$ \\
& E $10 \mu \mathrm{M}$ & $39.7 \pm 4.5$ & $36.3 \pm 6.1$ \\
& E-C & $-2.1 \pm 2.6$ & $2.3 \pm 3.7$ \\
\hline
\end{tabular}

Abbreviations and symbols are the same as in Table II.
Table IV. Effect of Decrease or Elimination of $\mathrm{Na}^{+}$from the Bath on the Basolateral Membrane Voltage

\begin{tabular}{llcc}
\hline & $\mathrm{NaCl}$ & HBC cell & LBC cell \\
\hline$n$ & $m M$ & & \\
VB & & 5 & 4 \\
& C 211.6 & $-67.8 \pm 3.8$ & $-73.8 \pm 4.4$ \\
& E 20 & $-70.0 \pm 3.9$ & $-74.0 \pm 4.3$ \\
$n$ & E-C & $-2.2 \pm 0.9$ & $-0.2 \pm 0.9$ \\
VB & & 5 & 4 \\
& C 211.8 & $-74.2 \pm 4.6$ & $-70.3 \pm 4.0$ \\
& E 0 & $-73.6 \pm 4.3$ & $-69.3 \pm 4.3$ \\
& E-C & $-0.6 \pm 0.4$ & $1.0 \pm 0.7$ \\
\hline
\end{tabular}

Abbreviations and symbols are the same as in Table II.

basolateral $\mathrm{K}^{+}$conductance whereas the $\mathrm{LBC}$ cell has a low basolateral $\mathrm{K}^{+}$conductance.

In the present study, we identified these cell types by the magnitude of the $\mathrm{VB}$ deflection in response to a rapid increase in $\mathrm{K}^{+}$concentration in the bathing fluid from 5 to $50 \mathrm{mM}$. Based on the data from 101 intracellular impalements, we confirmed that there are two different types of cells with regard to the voltage response to an abrubt change in $\mathrm{K}^{+}$concentration of the bathing fluid from 5 to $50 \mathrm{mM}$. We demonstrated that the replacement of $50 \mathrm{mM} \mathrm{Na}{ }^{+}$by $\mathrm{NH}_{4}^{+}$in the bathing fluid caused a rapid and reversible depolarization of the basolateral membrane of both cell types. However, in the $\mathrm{HBC}$ cell, the magnitude of the $\mathrm{VB}_{\mathrm{B}}$ deflection upon $50 \mathrm{mM} \mathrm{NH}_{4}^{+}$was only slightly greater than that induced by $50 \mathrm{mM} \mathrm{K}^{+}$. In contrast, in

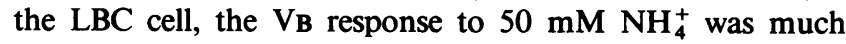
greater than that to $50 \mathrm{mM} \mathrm{K}^{+}$. It is possible that the VB deflection elicited by the ion concentration change in the bathing fluid is influenced by the circular current through the paracellular shunt pathway. To estimate the contribution of this component, we conducted similar studies in the tubules of which lumen was completely collapsed. Although the voltage deflections observed under this condition were tended to be slightly higher, they were not statistically significant. Therefore, the contribution of the circular current through the paracellular shunt pathway may be very small if any.

Table V. Effect of Ouabain on Basal $V B$ and on Voltage Responses of the Basolateral Membrane to $50 \mathrm{~K}^{+}$ or $50 \mathrm{NH}_{4}^{+}$Challenge in the Bath in the Hamster MAL

\begin{tabular}{lccc}
\hline & Ouabain & HBC cell & LBC cell \\
\hline$n$ & $\mu M$ & & \\
$\mathrm{VB}$ & & 7 & 4 \\
& C 0 & $-73.0 \pm 1.9$ & $-75.5 \pm 2.9$ \\
& E 10 & $-48.2 \pm 3.3$ & $-49.3 \pm 4.2$ \\
$\Delta \mathrm{VB}\left(50 \mathrm{~K}^{+}\right)$ & E-C & $-24.8 \pm 2.3^{\ddagger}$ & $-26.3 \pm 9.6^{*}$ \\
& C 0 & $40.2 \pm 2.0$ & $7.3 \pm 1.1$ \\
& E 10 & $36.0 \pm 1.5$ & $7.8 \pm 1.1$ \\
$\Delta \mathrm{VB}\left(50 \mathrm{NH}_{4}^{+}\right)$ & E-C & $-4.2 \pm 2.2$ & $0.5 \pm 1.3$ \\
& C 0 & $40.2 \pm 1.9$ & $41.8 \pm 1.7$ \\
& E 10 & $38.2 \pm 1.7$ & $40.3 \pm 1.4$ \\
& E-C & $-2.0 \pm 1.8$ & $-1.5 \pm 1.7$ \\
\hline
\end{tabular}

Abbreviations and symbols are the same as in Table II. ${ }^{*} P<0.01$; ${ }^{\ddagger} P<0.001$ as compared to zero. 
There are several possible ways by which an increase in $\mathrm{NH}_{4}^{+}$concentration causes the basolateral membrane to depolarize. First, it is possible that this maneuver may inhibit elecetrogenic $\mathrm{N}^{+}, \mathrm{K}^{+}$-pump, leading to depolarization of the basolateral membrane. This possibility was excluded by the observation that the voltage deflection by $\mathrm{NH}_{4}^{+}$challenge was not affected by pretreatment of the tubule with ouabain.

Second, if the addition of $\mathrm{NH}_{4} \mathrm{Cl}$ to the bath causes cell pH to alkalinize by diffusion of $\mathrm{NH}_{3}$, then intracellular $\mathrm{HCO}_{3}^{-}$ increases and depolarizes the basolateral membrane through $\mathrm{Na}^{+}-3 \mathrm{HCO}_{3}^{-}$cotransporter. In the present study, we confirmed that there is a $\mathrm{HCO}_{3}^{-}$conductance also in the basolateral membrane of the hamster MAL $(15,16)$. However, the VB deflection by $\mathrm{NH}_{4} \mathrm{Cl}$ in the bath is not accounted for by this conductance. Because the most experiments were conducted in the absence of $\mathrm{HCO}_{3}^{-}$in ambient fluid, the contribution of $\mathrm{HCO}_{3}^{-}$conductance can be ruled out.

Third, it is also possible that cytosolic alkalinization might increase $\mathrm{Cl}^{-}$conductance in the basolateral membrane, causing depolarization of the basolateral membrane. This possibility was excluded by the observation that the VB deflection caused by $\mathrm{NH}_{4}^{+}$was unchanged in the presence of $\mathrm{NPPB}, \mathrm{a} \mathrm{Cl}^{-}$ channel blocker (18). Under this experimental condition, NPPB may have had a definite inhibitory effect on the basolateral membrane $\mathrm{Cl}^{-}$conductance because it hyperpolarized the basolateral membrane.

Fourth, it is highly possible that $\mathrm{NH}_{4}^{+}$may depolarize the basolateral membrane by passing through a $\mathrm{K}^{+}$channel. The observation that in $\mathrm{HBC}$ cells the $\mathrm{VB}$ response to an increased $\mathrm{K}^{+}$concentration was only partially blocked by $\mathrm{Ba}^{2+}$ suggests that $\mathrm{a} \mathrm{Ba}^{2+}$-insensitive $\mathrm{K}^{+}$conductance exists in the basolateral membrane of the HBC cells. Although the inhibitory effect of $\mathrm{Ba}^{2+}$ on the $\mathrm{VB}$ deflection to $\mathrm{NH}_{4}^{+}$was less than that to $\mathrm{K}^{+}$in the $\mathrm{HBC}$, it is impossible to conclude that there is a conductance specific to $\mathrm{NH}_{4}^{+}$in this cell type. By contrast, in the LBC cell the $\mathrm{VB}$ response to $\mathrm{NH}_{4}^{+}$was considerably high despite the fact that the response to $50 \mathrm{~K}^{+}$was very low. Moreover, $10 \mathrm{mM}$ $\mathrm{Ba}^{2+}$ added to the bath suppressed the $\mathrm{VB}$ response to $50 \mathrm{~K}^{+}$to a level that was not different from zero. Under this condition, the response to $50 \mathrm{NH}_{4}^{+}$was decreased only by $23 \%$. These observations are compatible with the view that the voltage deflection caused by an $\mathrm{NH}_{4}^{+}$gradient is not entirely accounted for by the electrodiffusion of $\mathrm{NH}_{4}^{+}$through a $\mathrm{K}^{+}$channel, but rather through a pathway specific for $\mathrm{NH}_{4}^{+}$.

Bichara et al. (12) found an $\mathrm{NH}_{4}^{+}$conductance in the rat MAL fragments by measuring intracellular $\mathrm{pH}$ and voltage by fluorometry. However, it has not been determined whether the conductance was localized in the luminal or basolateral membrane. In the present study, we identified that the $\mathrm{NH}_{4}^{+}$conductance is located mainly in the basolateral membrane of the LBC cell. Bichara et al. (12) also reported that $1 \mu \mathrm{M}$ amiloride partially inhibited the $\mathrm{NH}_{4}^{+}$conductance. However, because Discala et al. (19) recently reported that a millimolar concentration of amiloride blocks $\mathrm{K}^{+}$conductance of the apical membrane of Necturus proximal tubular cells, the interpretation of the data on amiloride is somewhat difficult. Nevertheless, the observations that in the LBC cell $10 \mu \mathrm{M}$ amiloride inhibited the VB response to $50 \mathrm{NH}_{4}^{+}$without affecting the response to $50 \mathrm{~K}^{+}$ favor the view that the inhibitory effect of amiloride was more specific for the putative $\mathrm{NH}_{4}^{+}$conductance in the $\mathrm{LBC}$ cell.

It is of interest to note that similar $\mathrm{NH}_{4}^{+}$conductances were also found in rabbit proximal straight tubules (10) and Xeno- pus oocytes $(13,20)$. Burckhardt and Frömter (13) suggested that in Xenopus oocytes $\mathrm{NH}_{4}^{+}$may pass through a nonselective cation channel because the conductance was inhibited by various agents which are known to inhibit the nonselective cation channels. In the present study, however, we could not demonstrate any appreciable $\mathrm{Na}^{+}$conductance in the basolateral membrane of both cell types of the hamster MAL. Therefore, the $\mathrm{NH}_{4}^{+}$conductance in the hamster MAL may be distinct from the nonselective cation conductance.

Although it is unequivocal that there is an $\mathrm{NH}_{4}^{+}$conductance in the basolateral membrane of the LBC cell, the physiological significance of this conductance is unknown at present time. It is unlikely that this is a route of $\mathrm{NH}_{4}^{+}$exit at the basolateral membrane because an electrochemical gradient may be unfavorable for the $\mathrm{NH}_{4}^{+}$exit across the basolateral membrane. Therefore, it is possible that the putative $\mathrm{NH}_{4}^{+}$conductance of the basolateral membrane might act to reduce the net lumen to bath $\mathrm{NH}_{4}^{+}$flux by allowing the back flux of $\mathrm{NH}_{4}^{+}$from the bath to cytoplasm. In this regard, it should be noted that the conductance is predominant in the $\mathrm{LBC}$ cell. Because of the high $\mathrm{NH}_{4}^{+}$ conductance in the basolateral membrane, $\mathrm{NH}_{4}^{+}$concentration in the LBC cell might be higher than that in the $\mathrm{HBC}$ cell. This would in turn reduce the driving force for $\mathrm{NH}_{4}^{+}$entry across the apical membrane through $\mathrm{Na}^{+}-\mathrm{NH}_{4}^{+}-2 \mathrm{Cl}^{-}$cotransport. Functional significance of the cell heterogeneity in the MAL is unknown at present. Yoshitomi et al. (9) proposed that the LBC cell may participate in $\mathrm{K}^{+}$secretion whereas the $\mathrm{HBC}$ cell reabsorbs $\mathrm{K}^{+}$. Along the same line, we speculate that the $\mathrm{HBC}$ cell may participate in $\mathrm{NH}_{4}^{+}$reabsorption whereas the $\mathrm{LBC}$ cell may act to suppress $\mathrm{NH}_{4}^{+}$reabsorption. It is difficult to assess whether the latter participates in $\mathrm{NH}_{4}^{+}$secretion without knowing the mechanisms of $\mathrm{NH}_{4}^{+}$exit across the apical membrane. Further studies are obviously necessary to elucidate the functional significance of the $\mathrm{NH}_{4}^{+}$conductance in the basolateral membrane of the LBC cell of the hamster MAL.

\section{Acknowledgments}

We would like to express our thanks to Keiko Sakai for her secretarial assistance in preparing this manuscript and to Yuki Oyama for her technical assistance.

This work was supported in part by grants from Salt Science Foundation (No. 92037) and the Ministry of Education, Sciences, and Culture of Japan (No. 03454147).

\section{References}

1. Good, D. W., and M. A. Knepper. 1985. Ammonia transport in the mammalian kidney. Am. J. Physiol. 248 (Renal Fluid Electrolyte Physiol. 17):F459F471.

2. Knepper, M. A. 1991. $\mathrm{NH}_{4}^{+}$transport in the kidney. Kidney Int. 40:S95S102.

3. Good, D. W., M. A. Knepper, and M. B. Burg. 1984. Ammonia and bicarbonate transport by thick ascending limb of kidney. Am. J. Physiol. 247 (Renal Fluid Electrolyte Physiol. 26):F35-F44.

4. Garvin, J. L., M. B. Burg, and M. A. Knepper. 1988. Active $\mathrm{NH}_{4}^{+}$absorption by the thick ascending limb of rat kidney. Am. J. Physiol. 255 (Renal Fluid Electrolyte Physiol. 24):F57-F65.

5. Good, D. W. 1988. Active $\mathrm{NH}_{4}^{+}$absorption by the thick ascending limb: Inhibition by potassium. Am. J. Physiol. 255 (Renal Fluid Electrolyte Physiol. 24):F78-F87.

6. Kinne, R., E. Kinne-Saffran, H. Schutz, and B. Scholemann. 1986. Ammonium transport in medullary thick ascending limb of rabbit kidney: involvement of the $\mathrm{Na}^{+}, \mathrm{K}^{+}, \mathrm{Cl}^{-}$-cotransporter. J. Membr. Biol. 94:279-284.

7. Kikeri, D., A. Sun, M. L. Zeidel, and S. C. Hebert. 1989. Cell membranes impermeable to $\mathrm{NH}_{3}$. Nature (Lond.). 339:478-480.

8. Bleich, M., E. Schlatter, and R. Greger. 1990. The luminal $\mathrm{K}^{+}$channel of 
the thick ascending limb of Henle's loop. Pflügers Arch. Eur. J. Physiol. 415:449460.

9. Yoshitomi, K., C. Koseki, J. Taniguchi, and M. Imai. 1987. Functional heterogeneity in the hamster medullary thick ascending limb of Henle's loop. Pflugers Arch. Eur. J. Physiol. 408:600-608.

10. Guggino, W. B. 1986. Functional heterogeneity of early distal tubule of the Amphiuma kidney. Am. J. Physiol. 250 (Renal Fluid Electrolyte Physiol. 19):F430-F440.

11. Völkl, H., and F. Lang. 1991. Electrophysiology of ammonium transport in renal straight proximal tubules. Kidney Int. 40:1082-1089.

12. Bichara, M., E. Marty, P. Borensztein, and M. Paillard. $1990 . \mathrm{NH}_{4}^{+}$transport by cells of rat medullary thick ascending limb: electrogenic amiloride-sensitive pathway. J. Am. Soc. Nephrol. 1:647. (Abstr.)

13. Burckhardt, B.-C., and E. Frömter. 1992. Pathways of $\mathrm{NN}_{3} / \mathrm{NH}_{4}^{+}$permeation across Xenopus laevis oocyte cell membrane. Pflugers Arch. Eur. J. Physiol. 420:83-86.

14. Burg, M. B., J. Grantham, M. Abramow, and J. Orloff. 1966. Preparation and study of fragments of single rabbit nephron. Am. J. Physiol. 210:1293-1298.

15. Krapf, R. 1988. Basolateral membrane $\mathrm{H} / \mathrm{OH} / \mathrm{HCO}_{3}$ transport in the rat cortical thick ascending limb: evidence for an electrogenic $\mathrm{Na} / \mathrm{HCO}_{3}$ cotransporter. J. Clin. Invest. 82:234-241.

16. Kikeri, D., S. Azar, A. Sun, M. L. Zeidel, and S. C. Hebert. $1990 . \mathrm{Na}^{+}-\mathrm{H}^{+}$ antiporter and $\mathrm{Na}^{+}-\left(\mathrm{HCO}_{3}^{-}\right)_{n}$ symporter regulate intracellular $\mathrm{pH}$ in mouse medullary thick ascending limb of Henle. Am. J. Physiol. 258 (Renal Fluid Electrolyte Physiol. 27):F445-F456.

17. Greger, R. 1985. Ion transport mechanisms in thick ascending limb of Henle's loop of mammalian nephron. Physiol. Rev. 65:760-797.

18. Wangemann, P. M. Witter, A. Di Stefano, H. C. Englert, H. J. Lang, E. Schlatter, and R. Greger. 1986. Cl-channel blockers in the thick ascending limb of the loop of Henle: structure activity relationship. Pflügers Arch. Eur. J. Physiol. 407:S128-S141.

19. Discala, F., P. Hulin, F. Berachgar, G. Planelles, A. Edelman, and T. Anagnostopolos. 1992. Millimolar amiloride concentrations block K conductance in proximal tubular cells. Br. J. Pharmacol. 107:532-538.

20. Sasaki, S., K. Ishibashi, T. Nagai, and F. Marumo. 1992. Regulation mechanisms of intracellular $\mathrm{pH}$ of Xenopus laevis oocyte. Biochim. Biophys. Acta. 1137:45-51. 